\title{
IMPACT OF USING DIFFERENT TYPES OF GASOLINE ON SELECTED VEHICLE PROPERTIES
}

František Synák ${ }^{1}$, Ján Synák ${ }^{1}$

${ }^{1}$ Department of Road and Urban Transport, University of Žilina, Slovakia

\begin{abstract}
:
The article focuses on determining the impact of using different types of gasoline on selected vehicle properties. To perform the measurements, there were six types of gasoline chosen from different gas stations and they differed in price, octane rating, and in an amount of additives and biocomponents. The immediate effect of petrol on engine performance and torque, exhaust gas composition and fuel purchase costs was examined. The results have shown a relatively low impact of gasoline on a vehicle's dynamic properties. The most visible change was measured when comparing the most expensive fuel to the cheapest one. There was an increase in the engine torque from $156 \mathrm{Nm}$ to $160 \mathrm{Nm}$ measured. Such a difference is lower than the deviation of measuring. The differences measured in the composition of the exhaust gases are low. However, there is a significant impact in choice of gasoline on the costs of fuel purchase.
\end{abstract}

\section{ARTICLE HISTORY}

Received: 26.11.2020.

Accepted: 23.12.2020.

Available: 31.12.2020.

\section{KEYWORDS}

Acceleration, emissions, fuel, gasoline, power, torque

\section{INTRODUCTION}

A vehicle can be fuelled by gasoline with different octane rating, content of additives, and different biocomponents [1-3].

An octane rating is a measure of fuel's ability to withstand knocking when ignited in a mixture with air in the engine's cylinder [4]. The engine control unit receives a signal from a knock sensor about the engine knocking [5]. If there is a knock detected, it adjusts the parameters via actuators in order to prevent the engine from knocking since it is a negative phenomenon. If the control unit's activities needed for knocking to be eliminated are considerable, such as adjustment of ignition timing, setting of valve timing and so on, they can affect the engine power and composition of the exhaust gases as well [6]. Gasoline with octane rating from 95 up to 101 is the most commonly available fuel used in most EU countries $[7,8]$. As seen from $[9,10]$, due to change in gasoline with other octane ratings, actions that could lead to change in the engine power and torque, or in the composition of exhaust gases are usually not required.

There are various amounts of additives added into the gasoline. It is in order to increase the gasoline resilience against freezing or degradations caused by aging and alike [11]. Some distributors indicate that additives in the gasolines with higher price are those which aim to increase the engine power and reduce the amount of harmful emissions in the exhaust gases $[12,13]$. Despite this fact, the majority of the research results point out to low or almost no effect of gasoline additives supplementation [14]. The publication [15] has shown a significant increase in the engine power by $20 \%$. However, in this case, the amount of additives was substantially higher since they were refilled before measuring.

From January $1^{\text {st }}, 2020$, the share of biocomponent in the gasoline has increased from $5 \%$ up to $10 \%$ in the Slovak Republic [16]. The distributors applied this in the gasoline with octane rating of 95 . Concerning the gasoline with octane rating of 100 and more as well as premium gasoline, 
there was no increase in the share of biocomponent $[7,8,17]$. Increase in the share of biocomponent has been achieved by increase in ethanol and ETBE content [18]. ETBE - Ethyl tert-butyl ether production is both financially and technologically demanding, resulting in an additive that eliminates numerous disadvantages of ethanol [19]. According to distributors, gasoline with higher share of biocomponent entails no change in fuel consumption, same engine power and considerably lower $\mathrm{CO}_{2}$ content in the exhaust gases [20]. However, the research results have not proved a significant impact of ETBE on reducing the $\mathrm{CO}_{2}$ emissions [21]. Reduction of $\mathrm{CO}_{2}$ content in the exhaust gases has been done by multiply higher ETBE concentration in gasoline [22].

The purpose of the measurements from this article is to determine the impact of choice of commonly available gasoline on immediate change in dynamic properties of a vehicle, and in the composition of exhaust gases as well. In order to provide better information of the gasoline's impact on dynamic properties of a vehicle, there is a calculation of theoretical vehicle acceleration value given, on the basis of the data measured. The article also contains a calculation of the costs of gasoline purchase depending on kilometres driven and price of gasoline.

For the measurements, a regular naturally aspirated vehicle was chosen. The measurements comprised six different gasolines with different price, octane ratings and biocomponent content. Relating to this, an impact of gasoline on course of the engine power and torque's curves, and on a vehicle's ability to meet legislative requirements in relation to composition of the exhaust gases has been assessed. All the measurements were performed under laboratory conditions.

\section{MEASUREMENT METHODOLOGY}

The purpose of the measurements was to determine the impact of gasoline on selected vehicle features. These include the course of the engine power and torque's curves and a vehicle's ability to meet legislative requirements in relation to concentration of particular components in the exhaust gases.

The measurements were done with six different gasolines. Their basic data are given in Table 1 .
Table 1. Gasolines used during measurement

\begin{tabular}{|c|c|c|}
\hline Gasoline & Octane rating & Price per litre [€/I] \\
\hline A95 & 95 & 1.039 \\
\hline B95 & 95 & 1.209 \\
\hline C95 E10 & 95 & 1.110 \\
\hline D95 E5 & 95 & 1.30 \\
\hline E100 & 100 & 1.309 \\
\hline F101 & 101 & 1.226 \\
\hline
\end{tabular}

The fuel price per 1 litre belongs to the date of purchasing, i.e. April $23^{\text {rd }}, 2020$. Concerning gasoline D95 E5, the price corresponds to the date of December $29^{\text {th }}, 2019$. And consequently, there has been an increase in biocomponent content in the gasoline from $5 \%$ up to $10 \%$. Gasolines C95 E10 and D95 E5 are from the same gas station. According to the distributor, gasoline B95 in comparison with A95 is being supplemented by additives in order to increase the vehicle's performance and to reduce the fuel consumption and emissions. The gasoline A95 was from the gas station offering the cheapest gasolines all around.

During the measurements, a vehicle tank was replaced by another tank in order to avoid gasoline to be mixed. Thus, after measuring with one type of gasoline, the external tank was emptied and further replenished by new gasoline. After adding new gasoline into the tank with a fuel pump, a vehicle drove about $20 \mathrm{~km}$, and then the tank with new gasoline was emptied and further replenished by the same one. This avoided new gasoline to be mixed with the previous one in the vehicle fuel system. And, the control unit was able to adapt to other types of fuel [23].

Table 2 shows the technical data on the vehicle used in the measurements.

Table 2. Vehicle used for measuring [24]

\begin{tabular}{|c|c|}
\hline Name & Kia Ceed 1.6 CVVT \\
\hline Engine & Spark-ignition \\
\hline Engine code & $92 \mathrm{~kW} / 6,300 \mathrm{rpm}$ \\
\hline Engine power/speed & $154 \mathrm{Nm} / 4,200 \mathrm{rpm}$ \\
\hline Engine torque/speed & $1.2 \mathrm{l} .100 \mathrm{~km} \cdot \mathrm{h}^{-1}$ \\
\hline Average fuel consumption & $1,230 \mathrm{~kg}$ \\
\hline $\begin{array}{c}\text { Weight at the time of } \\
\text { measuring }\end{array}$ & $225 / 45 \mathrm{R} 17$ \\
\hline Tyre size & 3.52 \\
\hline Tyre energy class & 3.65 \\
\hline Gear ratio at 1st gear & 1.35 \\
\hline $\begin{array}{c}\text { Gear ratio in the transfer } \\
\text { case }\end{array}$ & \\
\hline $\begin{array}{c}\text { Coefficient of rotational } \\
\text { mass resistance at 1st } \\
\text { gear }\end{array}$ & \\
\hline
\end{tabular}


Measuring of the engine power and torque was done by cylinder test station MAHA MSR 1050. The measurement accuracy is $\pm 2 \%$ from the overall value of power measured [25]. While measuring the course of the engine power and torque's curves, a vehicle gradually reaches the maximum engine speed when having the penultimate gear used and acceleration pedal fully applied, and thus, it can be the course of cylinder power's curve determined. After the maximum engine speed is reached, a driver applies the clutch pedal and leaves the penultimate gear engaged. In this way, through vehicle coasting, the difference between the value of power delivered onto the wheels, respectively onto the dynamometer's cylinders, and the value of the engine flywheel is determined. The value of difference between the value of power delivered onto the dynamometer's cylinders and the value of the engine flywheel represents a power dissipation caused by mechanical losses [26].

Vehicle's ability to meet legislative requirements in relation to concentration of particular components in the exhaust gases has been measured by MAHA MGT 5 device. The composition of exhaust gases was determined at both idling speed and increased speed according to [27] Table 3 shows the legislative requirements for the vehicle used in the measurements.

Table 3. Legislative requirements in relation to concentration of exhaust gas components [27]

\begin{tabular}{|c|c|c|c|c|}
\hline Parameter & $\begin{array}{c}\text { Engine } \\
\text { speed } \\
{[\mathrm{rpm}]}\end{array}$ & $\begin{array}{c}\text { CO } \\
{[\%]}\end{array}$ & $\begin{array}{c}\text { HC } \\
{[\mathbf{p p m}]}\end{array}$ & $\boldsymbol{\lambda}[-]$ \\
\hline Idle speed & $\begin{array}{c}510- \\
810\end{array}$ & 0.40 & 100 & - \\
\hline Increased speed & $2,500-$ & 0.30 & 100 & $\begin{array}{c}0.97 \\
- \\
\end{array}$ \\
3,000 & & & 1.03 \\
\hline
\end{tabular}

Besides the components from Table $3, \mathrm{CO}_{2}$ and $\mathrm{O}_{2}$ concentrations were determined as well.

The costs of fuel purchasing after driving from 10 $000 \mathrm{~km}$ up to $80000 \mathrm{~km}$ per year were also being compared. For the comparison, the fuel consumption of $7.21 .100 \mathrm{~km}^{-1}$, and the price of litre of gasoline which is the same as in Table 1, were both taken into consideration. Gasoline D95 E5 was not considered in the calculations since it had been bought before a pandemic situation appeared and the costs had been considerably higher.

The impact of gasoline on a vehicle's ability to accelerate was determined by theoretical calculation based on the data measured during the engine power and torque's measurement. Theoretical difference in vehicle acceleration was calculated for those gasolines and engine speed at which the difference measured was the highest one.

The value of engine torque, vehicle mass, overall gear ratio, coefficient of rotational mass resistance, wheel radius, and vehicle rolling resistance are all important for vehicle acceleration [28].

The rolling resistance is calculated according to relation (1):

$$
O_{v}=m \cdot g \cdot f
$$

\section{$\mathrm{O}_{v}$ is the rolling resistance $\left.\mathrm{N}\right]$,} $m$ is the vehicle mass [ $\mathrm{kg}$ ],

$f$ is the coefficient of rolling resistance [-][29].

The second step of calculation is to determine the force on the wheels according to relation (2):

$$
F_{k}=\frac{M_{t} \cdot i_{c} \cdot \eta_{m}}{r}
$$

$F_{k}$ is the force on the wheels [N], $M_{t}$ is the engine torque [Nm], $\eta_{m}$ is the mechanical efficiency of the gear, $r$ is the wheel radius [m] [30].

The value of $\mathrm{M}_{\mathrm{t}}$ is being substituted by the values from measurements at which the biggest difference was measured as a result of different gasoline.

Overall gear ratio at 1 st gear is given by relation (3):

$$
i_{c}=i_{I} \cdot i_{r}
$$

$i_{c}$ is the overall gear ratio [-],

$i_{1}$ is the gear ratio at 1st gear [-], $i_{r}$ is the gear ratio in the transfer case [-].

The highest possible value of acceleration resistance can be calculated via relation (4):

$$
O_{a}=F_{k}-O_{v}
$$

$O_{a}$ is the acceleration resistance $[N]$,

$F_{k}$ is the force on the wheels [N],

$\mathrm{O}_{v}$ is the rolling resistance [N].

Then, the maximum vehicle acceleration can be calculated:

$$
a=\frac{o_{a}}{m \cdot \delta}
$$


$a$ is the vehicle acceleration $\left[m \cdot s^{-2}\right]$,

$O_{a}$ is the highest possible value of acceleration resistance,

$m$ is the vehicle mass [kg],

$\delta$ is the coefficient of rotational mass resistance [31].

\section{RESULTS}

\subsection{The cheapest gasoline and the most expensive gasoline}

Figure 1 shows the results of measuring the course of engine power and torque's curves when using both the cheapest gasoline A 95 and the most expensive gasoline E100. Left vertical axis shows the engine power in $\mathrm{kW}$, the horizontal axis shows the engine speed in revolutions per minute (rpm), and the right vertical axis represents the engine torque in $\mathrm{Nm}$. Red curve corresponds to the course of engine power on its flywheel, and the orange curve represents the course of engine torque. Thick curves are the values measured with the most expensive gasoline E100, and thin dashed curves are with the cheapest gasoline A95.

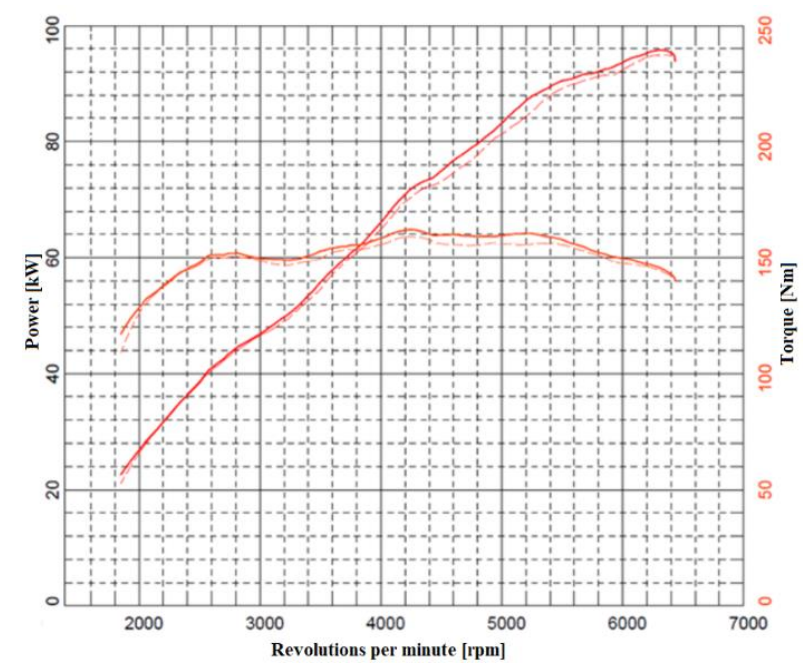

Fig.1. Comparison of the cheapest and most expensive gasoline

As seen from Figure 1, the biggest difference in the engine torque $-4 \mathrm{Nm}$ - has been measured at the engine speed of about 5,200 rpm, and in the engine power $-3 \mathrm{~kW}-$ at the same engine speed.

\subsection{The gasolines with different octane rating}

Figure 2 shows the measurement results where the thick line represents measuring with gasoline $A$ 95 with its octane rating 95 , and the dashed thin line represents measuring with gasoline F101 with its octane rating 101.

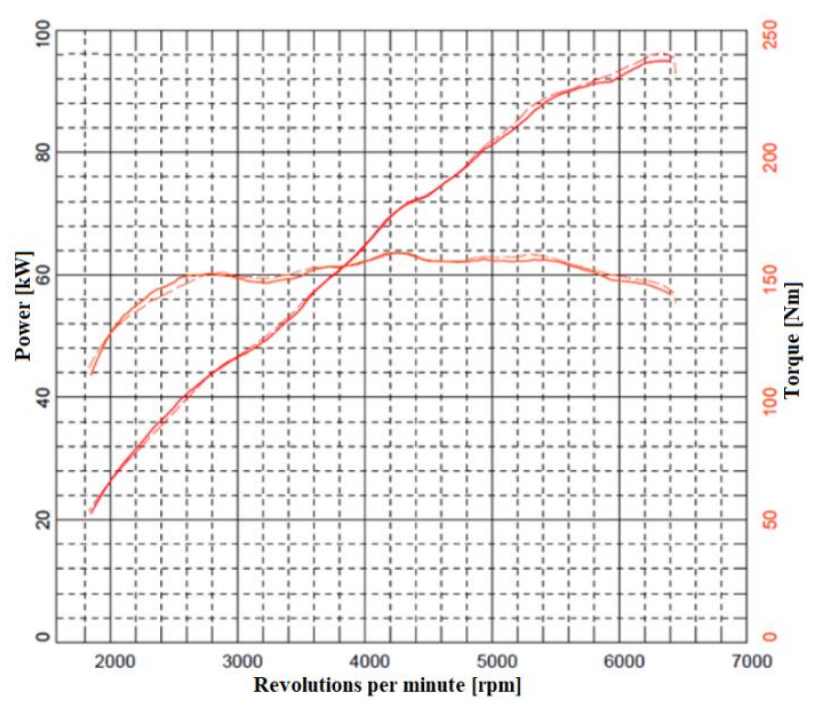

Fig.2. Comparison of gasolines with different octane rating

Concerning the engine torque, the biggest difference $-3 \mathrm{Nm}$ - has been seen at the area of engine speed of $2,770 \mathrm{rpm}$, and, concerning the engine power, the difference $-1.2 \mathrm{~kW}$ - has been seen at the engine speed of $6,287 \mathrm{rpm}$.

\subsection{The gasolines with different biocomponent content}

Comparison of gasoline C95E10 with biocomponent content up to $10 \%$ - the thin dashed curve, to the gasoline D95E5 with biocomponent content up to $5 \%$ - the thick curve, is shown in Figure 3.

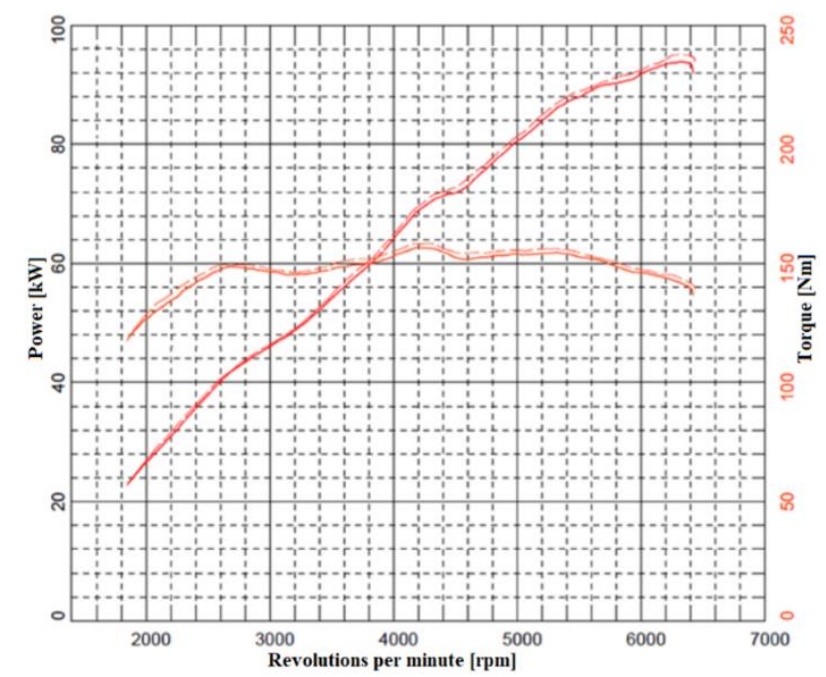

Fig.3. Comparison of gasolines with different biocomponent content

When comparing the gasolines from the same gas station but with different biocomponent 
content, there were both maximum differences in the engine torque $-2.5 \mathrm{Nm}$ - and in the engine power $-1.2 \mathrm{~kW}$ - measured at the engine speed of 4,600 rpm.

\subsection{Maximum values measured with particular gasolines}

For better transparency, the results of impact of gasoline on the engine power and torque are also given in Table 4. Table 4 shows the maximum values of engine torque in $\mathrm{Nm}$, and maximum values of engine power in $\mathrm{kW}$. Besides these, there is also the engine speed at which the values were measured given in rpm.

Table 4. Maximum values measured with particular gasolines

\begin{tabular}{|l|l|l|}
\hline Gasoline & $\begin{array}{c}\text { Highest engine } \\
\text { torque } \\
\text { [Nm]/Engine } \\
\text { speed [rpm] }\end{array}$ & $\begin{array}{c}\text { Highest engine } \\
\text { power [kW]/ } \\
\text { Engine speed } \\
\text { [rpm] }\end{array}$ \\
\hline A95 & $158.0 / 4,221$ & $94.9 / 6,284$ \\
\hline B95 & $159.8 / 4,260$ & $95.6 / 6,295$ \\
\hline C95E10 & $159.1 / 4,290$ & $95.0 / 6,300$ \\
\hline D95 E5 & $156.6 / 4,195$ & $93,8 / 6,320$ \\
\hline E100 & $162.0 / 4,220$ & $95.7 / 6,285$ \\
\hline F101 & $158.8 / 4,240$ & $96.1 / 6,290$ \\
\hline
\end{tabular}

As seen from Table 4, change in gasoline has only led to minimum differences in the engine power and torque.

\subsection{The impact of gasoline on acceleration}

The impact of gasoline on acceleration was calculated for the situation, at which the highest difference in the engine torque due to change in the gasoline, was measured. That situation occurred while measuring with gasoline $\mathrm{A} 95$ and E100 (Figure 1). The biggest difference measured was $4 \mathrm{Nm}$ at the engine speed of 5,200 rpm. When using gasoline A95, the engine reached $156 \mathrm{Nm}$ and when using the gasoline E100, the engine reached $160 \mathrm{Nm}$. After substituting the values from Table 2 and Figure 1 into formulas 1 and 2, the force delivered onto the wheels has been calculated for the gasoline $\mathrm{A} 95$ as $5,944 \mathrm{~N}$ and for $\mathrm{E} 100$ as $6,099 \mathrm{~N}$. After the substitution into formulas 3 and 4 , it has been calculated that when using the gasoline A95, it is possible to reach the maximum theoretical acceleration of $3.58 \mathrm{~m} . \mathrm{s}^{-2}$, and $3.73 \mathrm{~m} . \mathrm{s}^{-2}$ when using E100, all two at first gear used.

\subsection{Impact of gasoline on composition of the exhaust gases}

The impact of gasoline on a vehicle's ability to meet legislative requirements in relation to composition of the exhaust gases is evident from Table 5 and Table 6.

Table 5. Impact of gasoline on composition of the exhaust gases - idle speed

\begin{tabular}{|c|c|c|c|c|c|}
\hline Gasoline & $\begin{array}{c}\mathrm{CO} \\
{[\%]}\end{array}$ & $\begin{array}{c}\mathrm{HC} \\
{[\mathbf{p p m}]}\end{array}$ & $\begin{array}{c}\boldsymbol{\lambda} \\
{[-]}\end{array}$ & $\begin{array}{c}\mathbf{C O}_{2} \\
{[\%]}\end{array}$ & $\begin{array}{c}\mathbf{O}_{2} \\
{[\%]}\end{array}$ \\
\hline A95 & 0.00 & 7 & 1.003 & 15.42 & 0.08 \\
\hline B95 & 0.00 & 5 & 1.002 & 15.43 & 0.07 \\
\hline C95E10 & 0.01 & 8 & 1.003 & 15.50 & 0.07 \\
\hline D95 E5 & 0.01 & 10 & 1.002 & 15.42 & 0.08 \\
\hline E100 & 0.00 & 7 & 1.003 & 15.44 & 0.09 \\
\hline F101 & 0.01 & 9 & 1.003 & 15.39 & 0.08 \\
\hline
\end{tabular}

Table 6. Impact of gasoline on composition of the exhaust gases - increased speed

\begin{tabular}{|c|c|c|c|c|c|}
\hline Gasoline & $\begin{array}{c}\mathbf{C O} \\
{[\%]}\end{array}$ & $\begin{array}{c}\mathbf{H C} \\
{[\mathbf{p p m}]}\end{array}$ & $\begin{array}{c}\boldsymbol{\lambda} \\
{[-]}\end{array}$ & $\begin{array}{c}\mathbf{C O}_{2} \\
{[\%]}\end{array}$ & $\begin{array}{c}\mathbf{O}_{2} \\
{[\%]}\end{array}$ \\
\hline A95 & 0.07 & 9 & 1.000 & 15.33 & 0.07 \\
\hline B95 & 0.05 & 13 & 1.003 & 15.34 & 0.06 \\
\hline C95E10 & 0.04 & 12 & 1.002 & 15.25 & 0.09 \\
\hline D95 E5 & 0.03 & 8 & 1.001 & 15.52 & 0.08 \\
\hline E100 & 0.04 & 12 & 1.002 & 15.34 & 0.09 \\
\hline F101 & 0.03 & 13 & 1.002 & 15.37 & 0.09 \\
\hline
\end{tabular}

The choice of gasoline has had minimal impact on composition of the exhaust gases, and the vehicle has been able to meet all the legislative requirements while using each of selected gasoline.

\subsection{The costs of fuel purchase depending on gasoline price}

The costs of fuel purchase depending on gasoline price are shown in Figure 4. The gasoline D95 E5 was not taken into the results since it was bought at the time other than the rest of gasoline and its price significantly differed.

Lower axis shows the number of kilometres driven per year, and the vertical axis shows the costs of fuel purchasing in Euros.

As seen from Figure 4, the differences in costs of fuel purchasing are increasing with the number of kilometres driven. 


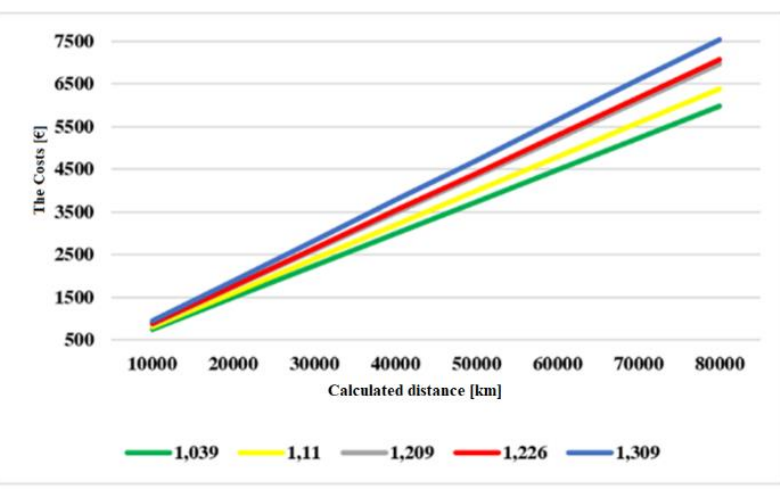

Fig.4. The costs of fuel purchase depending on gasoline price

Figure 5 shows the difference in costs of gasoline purchase depending on number of kilometres driven. The difference calculated is related to purchase of both the cheapest gasoline A95 and most expensive gasoline E100.

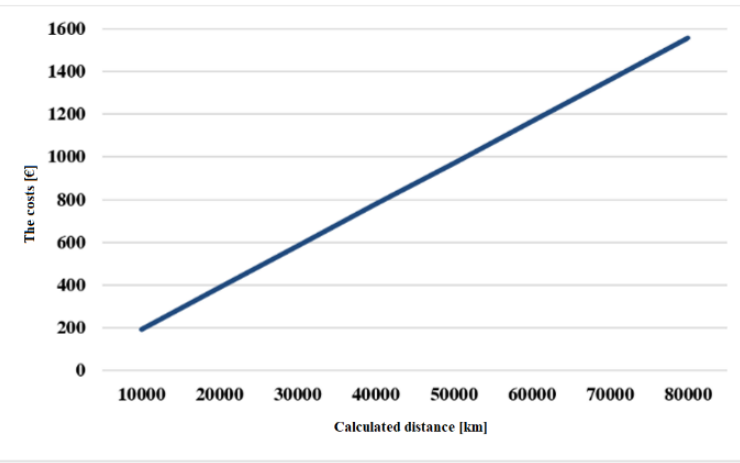

Fig.5. The difference in costs of gasoline purchase depending on number of kilometres driven

Using cheaper gasoline can reduce the fuel costs, especially when there is a higher number of kilometres driven per year, as seen in Figure 5.

\section{CONCLUSION AND DISCUSSION}

The purpose of the article was to determine the impact of gasoline used on the engine torque, costs of fuel purchasing, vehicle performance, its ability to accelerate and to meet legislative requirements in relation to composition of the exhaust gases.

Concerning the engine power and torque, there was only minimal impact seen. The biggest difference when using the cheapest and most expensive gasoline was $4 \mathrm{Nm}$ and $3 \mathrm{~kW}$ as seen in Figure 1. Such a difference is small and in common road traffic difficult to be noticed, although the difference was measured at a broader spectrum of the engine speed, from $3,200 \mathrm{rpm}$ up to the maximum of engine speed [32].

The purchase of $26 \%$ more expensive gasoline resulted in an increase in the engine torque by $2.5 \%$ and in the engine power by $3.5 \%$. While measuring the engine power and torque, the acceleration pedal is fully applied and, thus, the control unit indicates the maximum amount of fuel. The same amount of fuel was injected in both cases and, therefore, the difference measured was a result of increase in engine energy efficiency, i.e. reduction of specific fuel consumption [33]. Reducing specific fuel consumption and keeping the same amount of fuel led to increase in the engine power. However, increase in the engine power and torque was low at the level of the cylinder test station MAHA MSR 1,050 's deviation of measuring.

Similar results have been also measured while measuring the gasoline A95 with octane rating 95 and F101 with octane rating 101 (the second most expensive gasoline), see Figure 2 . The differences measured have been slightly smaller as when comparing A95 and F101 fuels. However, both cases imply small differences. When compared to the results from publications [34-36], the differences measured have been considerably smaller. It can be due to fact that the composition of gasoline, the amount and features of additives differ in each state. The results are affected by vehicle used in measurements as well. While measuring with a vehicle that is turbocharged, the differences have been higher regarding octane rating [37-39]. Among the publications compared, the highest increase in the engine power as a result of gasoline octane rating has been measured in the publication [40], see Figure 6.

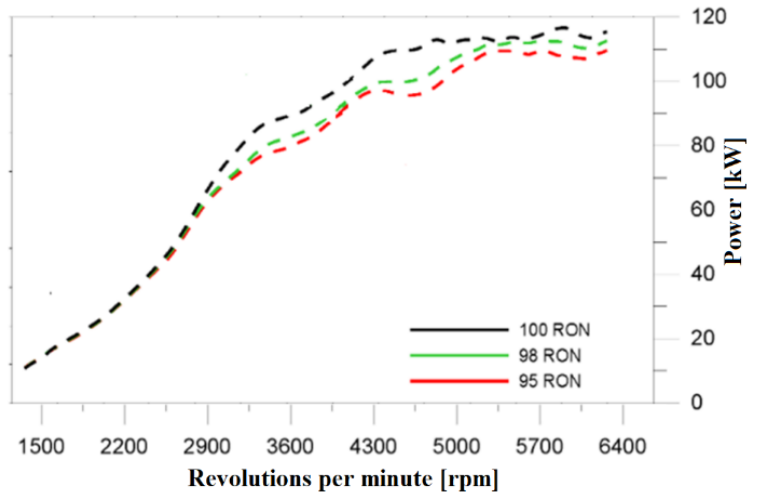

Fig.6. The gasoline octane rating and engine power [40]

As seen from Figure 6, the impact of gasoline octane rating on engine power has evinced predominantly in the higher engine speed. The higher engine speed is also connected with the stronger effect of turbocharger, and, thus, there is a higher inclination to knocking [41]. However, the difference engine power was not only a result of change in octane rating, but there were other 
factors such as the amount of biocomponent and additives in gasoline and many others [42].

The results from measuring the gasolines C95 E10 and D95 E5 refer to higher engine power and torque covering most of the engine speed area in relation to $\mathrm{C} 95 \mathrm{E} 10$. The reason can also lie in the fact that gasoline D95 E5 was stored in a tank of another vehicle for about 4 months, and it could lead to its degradation [43]. Difference in the engine torque is of about $2 \%$, and in the engine power it reaches the value of $1.6 \% .5 \%$ difference in the biocomponent content in gasoline caused only a slight change in the engine torque. A major change in the course of engine power and torque would probably happen only after a higher share in biocomponent content. In most cases, higher share in biocomponent content leads to reduction of the engine power and torque as seen in the publications [44-46].

Low impact of gasoline on dynamic properties of a vehicle has been also proved by calculation focusing on theoretical vehicle acceleration. Despite the calculation had being related to the highest difference measured among all the measurements, the calculated differences of force delivered onto the wheels as well as vehicle acceleration were small. When using the cheapest gasoline, the theoretical vehicle acceleration has reached $3.58 \mathrm{~m} . \mathrm{s}^{-2}$ and $3.73 \mathrm{~m} . \mathrm{s}^{-2}$ when using the most expensive one. The difference of $0.15 \mathrm{~m} \cdot \mathrm{s}^{-2}$ in acceleration is very small. What is more, such a difference has covered only a small spectrum of the engine speed of approximately $250 \mathrm{rpm}$.

Based on the data comparison from Table 3 and Table 5 and Table 6 , it can be said that, in this case, gasoline did not affect the vehicle' $s$ ability to meet legislative requirements in relation to composition of the exhaust gases. In all cases the vehicle has complied with road traffic driving and the values of assessed components has been almost constant. Thus, there has not been shown an impact of choice of gasoline on reducing the gaseous emissions that have adverse effects on human health [47]. Fueling the gasoline with higher octane rating and which is of higher price does not have any immediate effect in the case of a vehicle that was used for this measuring. At the same time, the increase in costs of fuel purchasing is relatively high as seen in Figures 4 and 5 as well. However, this article does not focus on the long-term impact of fuel on particular vehicle parameters. This kind of measuring would require two same vehicles that are running under completely identical conditions with different fuels.

Besides the methodology of laboratory experiments, determining the impact of gasoline on selected vehicle characteristics can be also done by computer modelling as seen in $[48,49]$. Computer simulations can be used for determining the impact of octane rating, additives, and biocomponent in gasoline on the course of the engine power, its combustion and knocking [50-52]. Via computer modelling, there can be also a simulation of the amount of emissions produced [53,54]. Despite all the possibilities of computer modelling, experimental measurements are still irreplaceable, as for their ability to verify the accuracy of computer modelling measurement results. The measurement results in this article are affected by the characteristics and parameters of a particular vehicle used for measuring. These include the engine's technical condition, the piston rings' tightness, the efficiency of a catalytic converter, the lambda sensor's immediate technical condition, the intensity of a lambda sensor's voltage surge, and many others. Thus, the results reflect the impact of choice of gasoline in relation to a common used vehicle, it means in a vehicle commonly seen in road traffic, and, this has been an intention of the article.

Based on the measurements performed, it can be said that from the short-term point of view, the price of gasoline, its octane rating or the amount of biocomponent has not a significant effect on dynamic properties of a vehicle, or on composition of the exhaust gases.

\section{ACKNOWLEDGEMENTS}

This research was funded by the Slovak scientific grant agency VEGA of the Ministry of 472 Education-no. 1/0436/18-Externalities in road transport, an origin, causes and economic impacts of transport 473 measures.

\section{REFERENCES}

[1] C.M. Wang, S. Zeraati-Rezaei, L.M. Xiang, H.M. $\mathrm{Xu}$, Ethanol blends in spark ignition engines: RON, octane-added value, cooling effect, compression ratio, and potential engine efficiency gain. Applied energy, 191, 2017: 603619.

https://doi.org/10.1016/i.apenergy.2017.01.0 $\underline{81}$ 
[2] I. Janoško, P. Feriancova, The effect of diesel additive on emissions and engine performance. Proceeding of 7 th international conference on trends in agricultural engineering 2019 (TAE), Prague, Czech Republic, 2019, pp.225-230.

[3] L.V. Amaral, N.D.S.A. Santos, V.R. Roso, R. Sebastiao, F. Pujattti, Effects of gasoline composition on engine performance, exhaust gases and operational costs. Renewable and sustainable energy reviews, 135, 2021: 110196. https://doi.org/10.1016/i.rser.2020.110196

[4] C.S. Wibowo, B. Sugiarto, A. Zikra, A. Budi, T. Mulya, Maymuchar, The Effect of GasolineBioethanol Blends to The Value of Fuel's Octane Number, 3rd International tropical renewable energy conference sustainable development of tropical renewable energy ( $i$ TREC 2018), Kuta, Bali, Indonesia, Vol.67. https://doi.org/10.1051/e3sconf/2018670203 $\underline{3}$

[5] D. Korenčiak, M. Gutten, J. Adamec, A. Glowacz, A. Cichy, Analysis of engine knock sensor. Communications - Scientific Letters of the University of Zilina, 20 (1), 2018: 37-41.

[6] H. Song, H.J. Kim, Effects of knocking on the performance and emissions of a single cylinder $\mathrm{Sl}$ engine fueled with a fuel blend of iso-octane and aromatic hydrocarbons. Fuel, 279, 2018: 118464.

https://doi.org/10.1016/i.fuel.2020.118464

[7] V. Valdenaire, H. Hamje, High-octane petrol (HOP) study: making gasoline relevant for the future of road transport, https://www.concawe.eu/wp content/uploads/High-octane-petrol-HOParticle.pdf (Accessed 15.10.2020)

[8] M. Mikušová, A. Torok, P. Brida, Technological and economical context of renewable and nonrenewable energy in electric mobility in Slovakia and Hungary. Ngoc-Thanh Nguyen, et al. (eds), 10th International Conference on Computational Collective Intelligence - Special Session on Intelligent Sustainable Smart Cities (ICCCI 2018), LNCS, 11056 LNAI, Springer, Heidelberg, 2018, pp.429-436.

[9] C.M. Wang, A. Prakash, A. Aradi, R. Cracknell, H.M. Xu, Signification of RON and MON to modern DISI engide. Fuel, 209, 2017: 172-183. https://doi.org/10.1016/i.fuel.2017.07.071

[10] A. Prakash, C.M. Wang, A. Janssen, A. Aradi, R. Cracknell, Impact of fuel sensitivity (RON MON) on engine efficiency. SAE International journal of fuel and lubricants, 10 (1), 2017: 115125.

https://doi.org/10.4271/2017-01-0799

[11] E. Magaril, R. Magaril, Improving the environmental and performance characteristics of vehicles by introducing the surfactant additive into gasoline. Environmental science and pollution research, 23 (17), 2016:17049-17057. https://doi.org/10.1007/s11356-016-6900-1

[12] Slovnaft extra drive 95 Additised gasoline for customers with high expectations, Online: https://slovnaft.sk/en/products/fuels/gasolin es/slovnaft-extra-drive-95/ (Accessed 15.10.2020)

[13] OMV MaxxMotion Gasoline, Online: https://www.omv.sk/sk-sk/cerpaciestanice/omv-maxxmotion/omv maxxmotionbenzin (Accessed 15.10.2020)

[14] I. Janoško, P. Kuchár, Evaluation of the fuel commercial additives effect on exhaust gas emissions, fuel consumption and performance in diesel and petrol engine. Agronomy research, 16 (3), 2018: 737- 748. https://doi.org/10.15159/AR.18.144

[15] K.F. Naser, H.R. Al-Hamadiny, M.H. Waroish, Influences of using fuel additives on a performance and emissions of $\mathrm{Sl}$ engine. Technology reports of Kansai university, 62 (3), 2020: 957-765.

[16] Commission recommendation of 18 June 2019 on the draft integrated National Energy and Climate Plan of Hungary covering the period 2021-2030.

[17] Slovnaft drive 95 Top quality gasoline, https://slovnaft.sk/en/products/fuels/gasolin es/slovnaft-drive-95/ (Accessed 15.10.2020)

[18] T. Skrucany, S. Semanova, S. Milojević, A. Ašonja, New Technologies Improving Aerodynamic Properties of Freight Vehicles. Applied Engineering Letters, 4 (2), 2019: 48-54. https://doi.org/10.18485/aeletters.2019.4.2.2

[19] E.W. Menezes, R. Catulana, Optimization of the ETBE (ethyl tert-butyl ether) production process. Fuel processing technology, 89 (11), 2008: 1148-1152.

https://doi.org/10.1016/i.fuproc.2008.05.006

[20] E. Stríž, Slovnaft: Most cars are fully compatible with E10 petrol, it is standard abroad, Autonoviny, 2020. https://www.autoviny.sk/reportaze/120630/s lovnaft-vacsina-aut-je-plne-kompatibilnych-s- 
benzinom-e10-v-zahranici-je-standardom

(Accessed 17.10.2020)

[21] I. Schifter, U. Gonzáles, M. González, Effects of ethanol, ethyl-tert-butyl ether and dimethylcarbonate blends with gasoline on SI engine. Fuel, 183, (1), 2016: 253-261.

https://doi.org/10.1016/j.fuel.2016.06.051

[22] L.M. Rodríguez, F. Gutíerrez, Y. Doce, Physical properties of gasoline, isobutanol and ETBE binary blends in comparison with gasoline ethanol blends. Fuel, 166, (15), 2016: 73-78. https://doi.org/10.1016/i.fuel.2015.10.106

[23] F. Synák, J. Synák, T. Skrúcaný, S. Milojevic, Modification of engine control unit data and selected vehicle characteristics. Applied Engineering Letters, 4 (4), 2019: 120-127. https://doi.org/10.18485/aeletters.2019.4.4.3

[24] Kia Ceed 1.6 CVVT, https://www.carsdata.com/en/kia-ceed-1.6-cvvt-x-traspecs/18900 (Accessed 17.10.2020)

[25] B. Šarkan, O. Stopka, Quantification of road vehicle performance parameters under laboratory conditions. Advances in science and technology-research journal, 12 (3), 2018: 1623.

https://doi.org/10.12913/22998624/92107

[26] B. Šarkan, O. Stopka, A. Chovancová, Kuranc, Simulating Real Driving Conditions on the Single Roller Dynamometer: a Case Study in Terms of the Fuel Consumption Measurement, $X I$ International science-technical conference automotive safety, Častá Papiernička, Slovakia, 2018.

[27] Decree No. 138/2018, Ministry of Transport and Construction of the Slovak Republic.

[28] J. Ondruš, J. Vrábel, E. Kolla, The influence of the vehicle weight on the selected vehicle braking characteristics. Transport Means Proceedings of the International Conference, Trakai, Lithuania, 2018.

[29] A. Soica, A. Budala, V. Monescu, S. Sommer, W.Owczarzak, Method of estimating the rolling resistance coefficient of vehicle tyre using the roller dynamometer. Proceedings of the institution of mechanical engineers part $d$ : Journal of automobile engineering, 234 (13), 2020: 3194-3204. https://doi.org/10.1177/0954407020919546

[30] R. Abrahám, T. Zubčák, R. Majdan, Drawbar pull of small tractor with special lug wheels, Proceeding of 7 th international conference on trends in agricultural engineering 2019, Prague, Czech republic, 2019, pp.2-7.
[31] J. Jagelčák, J. Zamečník, S. Peterssen, Comparison of acceleration acting on cargo in front and in rear part of semi- Trailer during braking with and without using the systems abs/eb. Communications - Scientific Letters of the University of Zilina, 18 (2), 2016: 76-82.

[32] T. Skrúcaný, M. Stopková, O. Stopka, S. Milojevic, Design of a daily-user methodology to detect fuel consumption in cars with spark ignition engine. Applied Engineering Letters, 5 (3), 2020: 80-86.

https://doi.org/10.18485/aeletters.2020.5.3.2

[33] M. Szabo, R. Majdan, S. Lindak, V. Hajdak, Special monitoring device for evaluation of driving style of car drivers, 15th international scientific conference: engineering for rural development, Jelgava, Latvia, 2016, pp.696701.

[34] A.K. Rashid, M.R. Abu Mansor, A. Racovitza, R. Chiriac, Combustion Characteristics of Various Octane Rating Fuels for Automotive Thermal Engines Efficiency Requirements. Technologies and materials for renewable energy, environment and sustainability, 157, 2019: 763-772.

https://doi.org/10.1016/j.egypro.2018.11.242

[35] J. Rodriguez-Fernandez, A. Ramos, J. Barba, D. Cardenas, J. Delgado, Improving Fuel Economy and Engine Performance through Gasoline Fuel Octane Rating. Energies, 13 (13) 2020: 3499.

https://doi.org/10.3390/en13133499

[36] R. Stradling, J. Williams, H. Hamje, D. Rickeard, Effect of Octane on Performance, Energy Consumption and Emissions of Two Euro 4 Passenger Cars. Transportation Research Procedia, 14, 2016: 3159-3168. https://doi.org/10.1016/j.trpro.2016.05.256

[37] S. Shuai, Y. Wang, X. Li, H. Fu, J. Xiao, Impact of Octane Number on Fuel Efficiency of Modern Vehicles. SAE Int. J. Fuels Lubr. 6(3), 2013: 702712.

https://doi.org/10.4271/2013-01-2614

[38] F. Jehlik, H. Lohse-Busch, S. Iliev, C. Hall, Capturing the Impact of Fuel Octane Number on Modern Gasoline Vehicles with Octane Indices. SAE International Journal of Fuels and Lubricants, 12, (2), 2019: 63-86. https://doi.org/10.4271/04-12-02-0005

[39] C.A. Bentoft, C. Callu, Cardenas Almena, MD et all., Phase 2: Effect of fuel octane on the performance of four Euro 5 and Euro 6 gasoline 
passenger cars, CONCAWE Reports, 2019, No.7, 2019.

https://www.concawe.eu/wp-

content/uploads/Phase-2-Effect-of-Fuel-

Octane-on-the-Performance-of-Four-Euro-5and-Euro-6-Gasoline-Passenger-Cars.pdf

(Accessed 20.10.2020)

[40] J. Rodríguez-Fernandéz, A. Ramos, J. Barba, D. Cárdenas, J. Delgado, Improving Fuel Economy and Engine Performance through Gasoline Fuel Octane Rating. Energies, 13 (13), 2020: 3499. https://doi.org/10.3390/en13133499

[41] N. Cavina, A. Businaro, G. Mancini, M. De Cesare, F.Covassin, S. Sgatti, Acoustic Emission Processing for Turbocharged GDI Engine Control Applications. SAE International journal of angines, 8 (4), 2015: 1660-1668.

https://doi.org/10.4271/2015-01-1622

[42] L. Partzsch, Biofuel research: Perceptions of power and transition. Energy, Sustainability and society, 7 2017: 14.

https://doi.org/10.1186/s13705-017-0116-1

[43] E.R. Streva, V.M.D. Pasa, J.R. Sodré, Aging effects on gasoline-ethanol blend properties and composition. Fuel, 90 (1), 2011: 215-219.

[44] M.N. Sasongko, W. Wyjaianty, Effect of ethanol addition on the performance and exhaust emissions of a spark ignition engine. Journal of mechanical engineering and sciences, 11 (2), 2017: 2734-2742.

https://doi.org/10.15282/imes.11.2.2017.14.0 248

[45] M. Mourad, K. Mahmoud, Investigation into Sl engine performance characteristics and emissions fuelled with ethanol/butanolgasoline blends. Renewable energy, 13, 2019: 762-771.

https://doi.org/10.1016/j.renene.2019.05.064

[46] M.I.N. Maárof, G.T. Chala, D. Gunnes, I. Saad, A study on the performance analysis of bioethanol produced from sugarcane molasses in SI engine, IOP Conference Series: Materials Science and Engineering, Vol.863, 012064, 2020.

https://doi.org/10.1088/1757899X/863/1/012064

[47] T. Skrúcaný, M. Kendra, O. Stopka, S. Milojević, T. Figlus, C. Csiszár, Impact of the Electric Mobility Implementation on the Greenhouse Gases Production in Central European Countries. Sustainability, 11 (18), 2019: 4948. https://doi.org/10.3390/su11184948
[48] H.A. Choudhury, S. Intikhab, S. Kalakul, R. Gani, N.O. Elbashir, Integration of computational modeling and experimental techniques to design fuel surrogates. Journal of natural gas science and angineering, 55, 2018: 585-594. https://doi.org/10.1016/i.jngse.2017.07.025

[49] C. Ciu, L. Zhang, Y. Ma, T. Billa, Z. Hou, Q. Shi, S. Zhao, C. Xu, M.T. Klein, Computer-Aided Gasoline Compositional Model Development Based on GC-FID Analysis. Energy and fuels, 32 (8), 2018: 8366-8373.

https://doi.org/10.1021/acs.energyfuels.8b01 $\underline{953}$

[50] J.A. Corrubia, J.M. Capece, N.P. Cernansky, D.L. Miller, R.P. Durrett, P.M. Najt, RON and MON chemical kinetic modeling derived correlations with ignition delay time for gasoline and octane boosting additives. Combustion and flame, 219, 2020: 359-372.

https://doi.org/10.1016/j.combustflame.2020 .05 .002

[51] D. Dodig, N.M. Radica, T. Santic, G. Radica, CFD Simulation for the Knock Analysis in the Internal Combustion Engine, 3rd International Conference on Smart and Sustainable Technologies (SpliTech 2018), Split, Croatia, 2018.

[52] O. Orynycz, K. Tucki, A. Wasiak, R. Mruk, Computer modelling of automobile engine performance as the source of implications for automobile technology management, IOP Conference Series: Materials Science and Engineering, 710 (1), 2019: 012007.

https://doi.org/10.1088/1757899X/710/1/012007

[53] F. Zuo, Z. Li, X. Lyu, Y Zhang,.., Prediction of gasoline engine exhaust emission based on BP neural network. Journal of Jiangsu university, 41 (3), 2020: 307-313.

https://doi.org/10.3969/j.issn.16717775.2020.03.010

[54] T. Korakianitis, S. Imran, N. Chung, H. Ali, D.R Emberson, R.J. Crookes, Combustion-response mapping procedure for internal-combustion engine emissions. Applied energy, 156, 2015: 149-158.

https://doi.org/10.1016/i.apenergy.2015.06.0 $\underline{39}$ 